\title{
Faunal diversity of Cladocera (Crustacea: Branchiopoda) with notes on biogeographically important species in the floodplain wetlands of the Subansiri River basin, India
}

\author{
Budhin Gogoi ${ }^{1,2,{ }^{*}}$, Francisco Diogo R. Sousa ${ }^{3}$ and Debangshu N. Das ${ }^{1}$ \\ ${ }^{1}$ Department of Zoology, Rajiv Gandhi University, Rono Hills, Doimukh 791112, Arunachal Pradesh, India \\ 2 Department of Zoology, North Bank College, Ghilamara 787053, Assam, India \\ ${ }^{3}$ Unidade Acadêmica Especial de Ciências Biológicas, Universidade Federal de Jataí - UFJ, BR364 km 195 n³800, CEP 75801615 , \\ Jataí, GO, Brazil
}

Received: 10 October 2017; Accepted: 16 July 2018

\begin{abstract}
The plankton samples collected from the Subansiri floodplain wetlands revealed a rich Cladocera assemblage of 55 species belonging to 30 genera and 7 families. The species richness represents $42 \%$ and $75 \%$ of the total amount of fresh water species reported from India and Assam, respectively. Chydoridae was the most speciose family, with 31 species, while Ilyocryptidae was represented by a single species. Sididae, Daphniidae, Bosminidae, Moinidae and Macrothricidae were represented by four, five, three, two and four species, respectively. The faunal composition is represented by cosmopolitan, tropical and oriental elements. The documentation of Diaphanosoma dubium, Latonopsis australis, Simocephalus mixtus, Chydorus sphaericus, Chydorus parvus, Chydorus ovalis, Alonella clathratula, Pleuroxus cf. denticulatus, Picripleuroxus quasidenticulatus, Celsinotum macronyx, Coronatella anodonta and Kurzia (Rostrukurzia) brevilabris has biogeographic importance. We provide brief geographical distributional remarks about these 12 species from the collected samples. This was a preliminary study, as the fauna from the Indian subcontinent is poorly documented, and requires a taxonomic revision as a whole. The faunistic diversity of cladocerans comprises a clear representation of a tropical cladoceran assemblage.
\end{abstract}

Keywords: Cladocera / Chydoridae / distribution / systematic / wetland

\section{Introduction}

Cladocera are a poorly known group of microcrustaceans, and their taxonomic enumeration remained poor during the twentieth century (Korovchinsky, 1997). The pioneer studies of Frey (1959, 1982a,b) and Smirnov (1971, 1976, 1992, 1996) along with continuous efforts of several other researchers around the world revealed about 700 valid species (Kotov, 2011). Taxonomic accounts are an essential base for a critical approach concerning the ecology and biogeography of these microcrustaceans and a rational assessment of their global diversity (Dodson and Frey, 2001). Thus, efforts in systematics, building of taxonomical capacity and the appraisal of the global richness of Cladocera have already increased in the Neotropics, South-East and East Asia (Elmoor-Loureiro, 2000; Maiphae et al., 2008; Kotov and Sinev, 2011).

\footnotetext{
*Corresponding author: budhinrgu2012@gmail.com
}

Although the cladoceran fauna of Australia, America (especially South America) and Europe can be considered well studied, further endeavours are necessary in Asia, for which the validity of many currently described species is still being debated (Forró et al., 2008; Maiphae et al., 2008; Kotov et al., 2013). In South-East (SE) Asia, Cladocera from Thailand can be considered well studied (Sanoamuang, 1998; Maiphae et al., 2008; Kotov, 2011; Sinev and Kotov, 2012; Van Damme and Maiphae, 2013; Van Damme and Sinev, 2013). Despite this, from the 298 formal species recorded from SE Asia, only 67 species were found to be valid and 68 have been registered as synonyms, while the remaining 163 are thought to represent "species complexes" (Korovchinsky, 2013). South-East Asia can be considered the most well-studied region from the Oriental zone, at least when concerning the subfamily Aloninae of the Chydoridae (Sinev, 2016; Sinev et al., 2017). Survey on Indian cladoceran species is still very scarce compared to other Asian countries, and the actual records of Indian species numbers remain obscure (Chatterjee et al., 2013; Padhye and Dumont, 2015). Fernando and Kanduru (1984) reported 130 species, Michael and Sharma (1988) 
reported 93 species, Raghunathan and Kumar (2003) reported 187 species and, more recently, Chatterjee et al. (2013) reported 133 species. Inadequate taxonomic analyses and the incongruences of the extant report on different taxa warrant the urgent need of confirmation of the diversity status of cladoceran species from India (Sharma and Sharma, 2008; Chatterjee et al., 2013; Padhye and Dumont, 2015).

The cladoceran fauna from floodplain lakes of American and European countries such as the Upper Paraná (Serafim-Júnior et al., 2003; Lansac-Tôha et al., 2009), Danube (Kiss, 2004; Illyova and Nemethova, 2005; Kiss and Scholl, 2009) and Acthafalya river basins (Davidson et al., 2000) were well documented. However, the study from Indian floodplain lakes are limited only to the reports of Khan (1987), Sharma and Sharma (2010) and Sharma (2008). The cladoceran fauna from floodplain wetlands of the Brahmaputra river basin of Assam (Sharma and Sharma, 2007, 2008, 2010, 2012; Sharma et al., 2015) are considered well documented, with 74 species being reported to date (Sharma and Sharma, 2014). In this regard, the zooplankton fauna, and more specifically the cladoceran fauna of the floodplain wetlands of the Subansiri River basin of Northeast India, still remain mostly unknown. The present investigation, therefore, intended to (i) document the fauna of Cladocera from the floodplain wetlands of the Subansiri River basin, (ii) evaluate their richness and species composition, and also (iii) perform a systematic revision of the species encountered in the region.

\section{Materials and methods}

\subsection{Study area}

The Subansiri River floodplain encompasses different categories of floodplain wetlands in its $4350 \mathrm{~km}^{2}$ catchment area in the plains of Assam. The study was conducted in three different types of wetland environments: Hatimora, a deep water rice field $\left(27^{\circ} .07^{\prime} \mathrm{N} 94^{\circ} .08^{\prime} \mathrm{E}\right)$, Morikhaboli, a floodplain lake $\left(27^{\circ} .06^{\prime} \mathrm{N} 94^{\circ} .08^{\prime} \mathrm{E}\right)$, and Halmora, an oxbow lake $\left(27^{\circ} .05^{\prime} \mathrm{N}\right.$ $\left.94^{\circ} .06^{\prime} \mathrm{E}\right)$. All these study areas are located between $27^{\circ} .02^{\prime}$ and $27^{\circ} .15^{\prime}$ North latitude and $93^{\circ} .99^{\prime}$ and $94^{\circ} .15^{\prime}$ East longitude (Fig. 1). The deep water rice field is a seasonal wetland, whereas the oxbow lake and the floodplain lake are perennial environments seasonally flooded by the Subansiri River. Floodplain lakes are locally known as beel, being characterized as wide, shallow and connected to rivers through channels during the monsoon season. Oxbow lakes (OL) are locally known as dubi, which are abandoned river courses generally occupied by small water bodies, which are connected to rivers during the wet season. Deep water rice fields (DWR), locally known as bao pathar, are traditional bao rice farming zones where the water remains for 4-6 months with water depth ranging from 0.50 to $2.0 \mathrm{~m}$ or more. These wetlands are rich in macrophyte species such as Leersia spp., Tapas spp., Eichhornia spp., Hydrilla spp., Hygroryza spp., Ipomea spp., Lemna spp., Pistia spp., Nymphaea spp., Nymphoides spp., Potamageton spp., Azolla spp., Utricularia spp. and Sagittaria spp.

\subsection{Sampling, sorting, quantification and identification}

A total of 120 plankton samples were collected from four selected sites in each wetland type from May 2013 to April

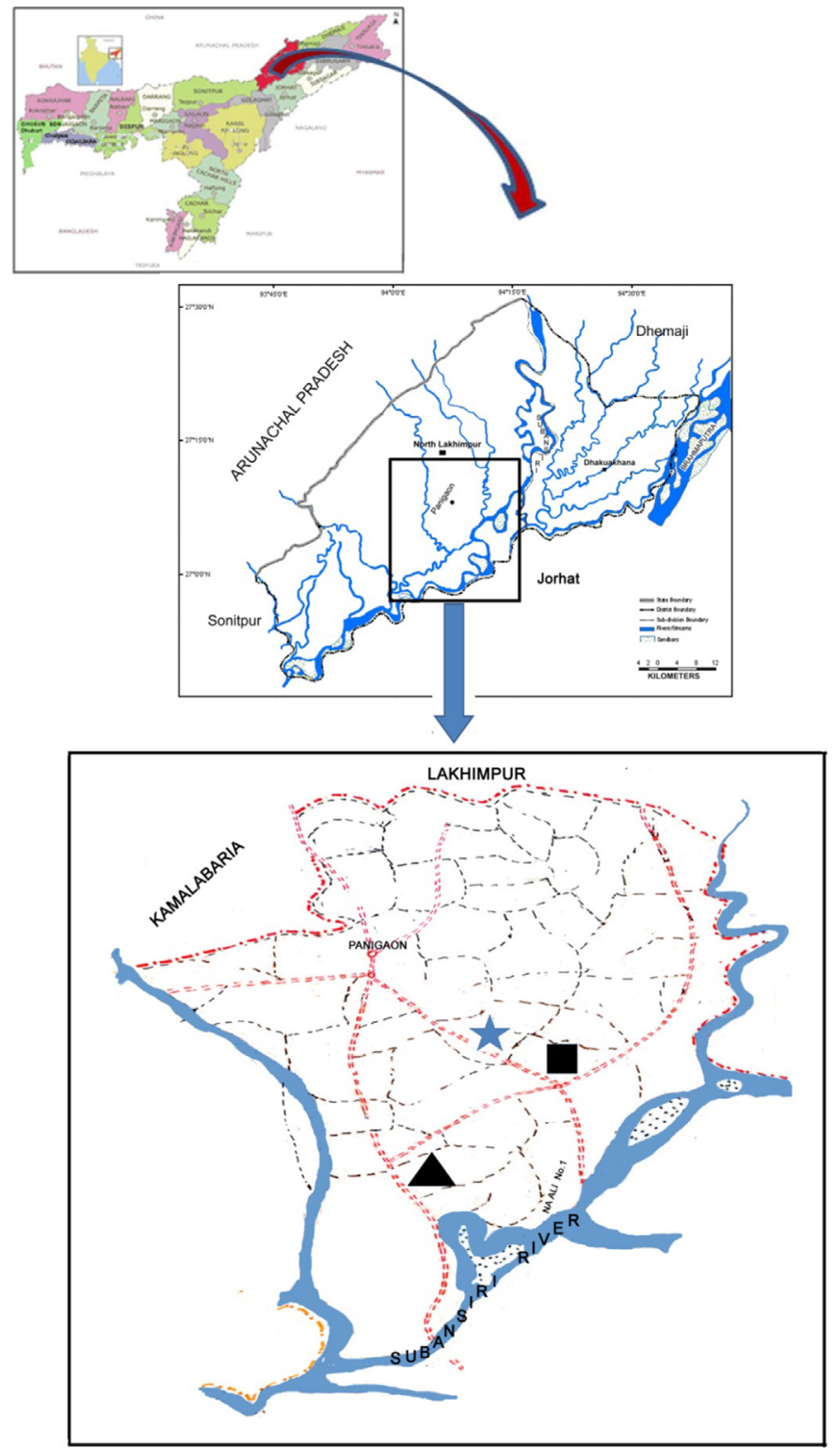

Fig. 1. Map showing the study areas in the Subansiri floodplain ( Hatimora DWR, Morikhaboli beel and $\mathbf{\Delta}$ Halmora dubi).

2015 (Fig. 1). Plankton samplings were performed by filtering $100 \mathrm{~L}$ of the subsurface water of the littoral and limnetic regions with a nylon cloth plankton net ( $60 \mu \mathrm{m}$ mesh size). The filtrated water collected in a vial attached to the bottom core of the plankton net was then transferred to labelled plankton vials and immediately preserved in 5\% formalin.

Afterwards, plankton samples were screened under a stereoscopic binocular light microscope (Nikon eclipse E200) for quantification and separation of different specimens of Cladocera. The isolated cladocerans were individually mounted in glycerin for qualitative studies. The specimens were examined under a Leica DM 5000 camera attached to a microscope fitted with an image analyzer, and then identified following Smirnov (1971, 1996), Michael and Sharma (1988), Subhash Babu and Nayar (2004); Kotov et al. $(2012,2013)$ and Pascual et al. (2014). We used specialized papers to aid in the 
identification of species of Macrothrix (Dumont et al., 2002; Kotov, 2008), Kurzia (Hudec, 2000; Padhye and Van Damme, 2015), Celsinotum (Rajapaksa and Fernando, 1985), Chydorus (Rajapaksa and Fernando, 1986a; Smirnov, 1996; Van Damme and Dumont, 2007), Alona (Sinev, 1999; Van Damme et al., 2010), Karualona (Dumont and Silva-Briano, 2000; Van Damme et al., 2013), Coronatella (Van Damme and Dumont, 2008; Sousa et al., 2015a), Notoalona (Rajapaksa and Fernando, 1987), Anthalona (Van Damme et al., 2011; Sinev and Kotov, 2012; Sousa et al., 2015b), Dadaya (Rajapaksa and Fernando, 1982a), Diaphanosoma (Korovchinsky, 1998, 2002), Pleuroxus (Hudec and Illyova, 1998; Chiambang and Dumont, 2004; Sinev and Sanoamuang, 2013), Simocephalus (Young et al., 2012), Bosmina (Taylor et al., 2002; Kotov et al., 2009), Bosminopsis (Rey and Vasquez, 1986; Kotov, 1999), and Ephemeroporus (Frey, 1982b; Smirnov, 1996). The specimens were deposited in the Laboratory of Fisheries and Aquatic Ecology of the Rajiv Gandhi University, Itanagar, India.

\subsection{Data analysis}

Species composition: The species composition was evaluated through occurrence constancy analysis for each type of floodplain wetland, obtained by dividing the number of sampling units in which a given species occurred by the total number of sampling units studied. Results were then multiplied by 100 . According to the obtained values of occurrence constancy, the species were classified as constant $(>50 \%)$, accessory (25-50\%) and accidental ( $>25 \%$ ) (Dajoz, 1983). To compare the species composition between different floodplain wetland types, the Bray-Curtis similarity index was calculated using the PAST software, version 3.07.

Species richness and species abundance curve: The species richness (Margalef's index) was estimated by using the PAST software, version 3.07.

Margalef's richness index (Brower and Zar, 1977)

$\mathrm{R}=\mathrm{S}-1 / \mathrm{ln} \mathrm{N}$

where $S=$ number of species, $N=$ total number of individuals in the sample.

The species abundance curve was prepared by plotting the abundances of species against their respective rank. The species rank was assigned on the basis of their relative abundance; with the most abundant species being assigned the 1 st rank, the second to the 2nd and so forth.

\section{Results}

\subsection{Species composition}

The 55 species ( 39 species in DWR, 53 species in both the floodplain lake and oxbow lake) represented seven families: Sididae, Daphniidae, Bosminidae, Moinidae, Macrothricidae, Ilyocryptidae and Chydoridae. These families are contained in two distinct orders: Ctenopoda and Anomopoda, both of which were documented in the entire study area (Tab. 1). Chydoridae was the most species-rich family, with 36 species, which represented about $64.5 \%$ of the species richness, while the Ilyocryptidae was represented by a single species. Sididae, Daphniidae, Bosminidae, Moinidae and Macrothricidae were represented by four, five, three, two and four species, respectively. Simocephalus mixtus (Sars, 1903) and Pleuroxus cf. denticulatus (Birge, 1879) are new records for the state of Assam. Eight species (Daphnia lumholtzi, Ceriodaphnia cornuta, Bosmina longirostris, Bosminopsis deitersi, Macrothrix triserialis, Chydorus sphaericus, Chydorus ventricosus, Chydorus cf. ovalis, Ephemeroporus barroisi, Celsinotum macronyx and Coronatella rectangula) were numerically dominant and collectively represented in more than $50 \%$ of the samples. Simocephalus mixtus, Bosmina cf. tripurae, Macrothrix spinosa, Chydorus parvus, Chydorus eurynotus, Pseudochydorus globosus, Picripleuroxus cf. quasidenticulatus, Flavalona cf. costata, Alona guttata, Notoalona globulosa, Karualona karua, Coronatella anodonta and Kurzia longirostris were represented in a range of $25-50 \%$ of the samples, and the rest of the listed species were rarely encountered.

The species composition was similar between the studied wetlands. The results indicated a faunal similarity of almost $80 \%$ between the Oxbow lake and the Floodplain lake. The similarity between the DWR, the OL and the FP was of $50 \%$ and $55 \%$, respectively (Bray-Curtis similarity analysis values were of 0.56 between the DWR and the FP, of 0.50 between the DWR and the OL, and of 0.79 between the OL and the FP).

\subsection{Species richness index and abundance curve}

The Margalef index indicated a spatial variation of the species richness among the studied ecosystems. The lowest value was observed in the DWR wetland, while the FP and OL presented similar values (Fig. 2). Regarding the abundance ranks, the DWR wetland exhibited dominant species with lower values compared to the FP and OL (Fig. 3). Another important difference between the wetland types was related to the set of dominant species. The non-planktonic species were the most abundant in the DWR, while typically planktonic species were the most abundant in the floodplain lake and the Oxbow lake (Fig. 3).

\section{Discussion}

River floodplains are heterogeneous landscapes (Ward et al., 1999) and hypothesized to be rich habitats harbouring high zooplankton diversity (Sharma and Sharma, 2008). We encountered a total of 55 species belonging to 30 genera under 7 families, revealing the speciose nature of cladoceran assemblages in the wetlands of the Subansiri floodplain. The species richness represents roughly $\sim 42 \%$ of the cladoceran species known from India as reported in a recent checklist by Chatterjee et al. (2013) and $~ 75 \%$ of the species richness known from the Brahmaputra basin, Assam, following reports of Sharma and Sharma (2014). The generic diversity of 31 genera was lower than the total of 47 genera known from India. The cladoceran composition was characterized by high generic diversity and the records of 31 genera closely corresponded to the previous report of 32 genera (Sharma et al., 2015) from the same state.

Chydoridae was the most species-rich family (31 species, 64.58\%) while Daphniidae, Bosminidae and Macrothricidae were subdominant groups. The observations agree with the notion that Chydoridae are a particularly diverse group of cladocerans, being typical of the tropical and subtropical 
Table 1. Checklist of species of Cladocera and their relative occurrences in the Subansiri floodplain wetlands (DWR: deep water rice field; FP: floodplain lake; OL: oxbow lake).

\begin{tabular}{lrrr}
\hline Taxa & OL & FP & $\begin{array}{l}\text { DWR } \\
\text { Relative } \\
\text { occurrences }\end{array}$ \\
\hline
\end{tabular}

Family: Sididae Baird, 1850

Diaphanosoma dubium (Manuilova, 1964)

Diaphanosoma excisum Sars, 1885

Diaphanosoma spp.

Latonopsis australis Sars, 1885 s.lat.

Family: Daphniidae Straus, 1820

Daphnia lumholtzi Sars, 1885

Ceriodaphnia cornuta Sars, 1885

Ceriodaphnia spp.

Simocephalus serrulatus (Koch, 1841)

Simocephalus mixtus Sars, 1903

Family: Bosminidae Baird, 1845 emend. Sars, 1865

Bosmina longirostris (Müller, 1776)

Bosmina cf. tripurae Kořinek et al., 1999

Bosminopsis deitersi Richard, 1895 s.lat.

Family: Moinidae Goulden, 1968

Moina micrura Kurz, 1874

Moinodaphnia macleayi (King, 1853)

Family: Macrothricidae Norman and Brady, 1867 emend. Dumont and

Silva-Briano, 1998

Macrothrix spinosa King, 1853

Macrothrix rosea (Jurine, 1820)

Macrothrix triserialis (Brady, 1886)

Guernella raphaelis Richard, 1892

Family: Ilyocryptidae Smirnov, 1976 emend. Smirnov, 1992

Ilyocryptus spinifer Herrick, 1882

Family: Chydoridae Dybowski and Grochowski, 1894 emend. Frey, 1967

Subfamily: Chydorinae Dybowski and Grochowski, 1894 emend. Frey, 1967

Chydorus sphaericus (Müller, 1776)

Chydorus ventricosus Daday, 1898

Chydorus parvus (Daday, 1898)

Chydorus cf. ovalis Kurz, 1874

Chydorus reticulatus Daday, 1898

Chydorus angustirostris Frey, 1987 s.lat

Chydorus eurynotus Sars, 1901. s.lat

Pseudochydorus globosus (Baird, 1843) s.lat

Ephemeroporus barroisi (Richard, 1894)

Dadaya macrops (Daday, 1898)

Disparalona caudata Smirnov, 1996

Alonella clathratula Sars, 1896

Alonella cf. excisa (Fischer, 1854)

Pleuroxus cf. denticulatus Birge, 1879

Pleuroxus cf. trigonellus (Müller, 1776)

Picripleuroxus cf. quasidenticulatus (Smirnov, 1996)

Subfamily: Aloninae Dybowski and Grochowski, 1894 emend. Frey, 1967

Flavalona cf. costata (Sars, 1862)

Alona affinis (Leydig, 1860) s.lat.

Alona guttata Sars, 1862

Flavalona cheni Sinev, 1999

Alona spp. 1

Alona spp. 2

Alona spp. 3

Notoalona globulosa (Daday, 1898)

Karualona karua (King, 1853)

Karualona spp.

$$
\begin{aligned}
& + \\
& + \\
& + \\
& + \\
& + \\
& + \\
& + \\
& + \\
& + \\
& + \\
& + \\
& + \\
& + \\
& +
\end{aligned}
$$

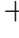

$+$

$+$

$+$

$+$

$+$

$+$

$+$

$+$

$+$

$+$

$+$

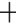

$+$

$+$

$+$

$\begin{array}{lll}+ & \mathrm{R} \\ + & \mathrm{R} \\ + & \mathrm{R} \\ + & \mathrm{R}\end{array}$

\section{$+$}

$+$

$+$

$-$

$+$

$\mathrm{R}$

$\mathrm{R}$
$\mathrm{R}$

$\mathrm{R}$

A

A

MA

$\mathrm{R}$

MA

A

MA

A

$\mathrm{R}$

$\mathrm{R}$

MA

$\mathrm{R}$

A

$\mathrm{R}$

$\mathrm{R}$

A

A

MA

MA

$\mathrm{R}$

R

MA

MA

A

R

R

R

R

R

$\mathrm{R}$

MA

MA

$\mathrm{R}$

MA

$\mathrm{R}$

MA

$\mathrm{R}$

$\mathrm{R}$

MA

MA

$\mathrm{R}$ 
Table 1. (continued).

\begin{tabular}{|c|c|c|c|c|}
\hline Taxa & $\mathrm{OL}$ & FP & DWR & $\begin{array}{l}\text { Relative } \\
\text { occurrences }\end{array}$ \\
\hline Celsinotum macronyx (Daday, 1898) & + & + & - & A \\
\hline Coronatella rectangula (Sars, 1862$)$ & + & + & + & A \\
\hline Coronatella cf. acuticostata (Stingelin, 1904) & + & - & + & $\mathrm{R}$ \\
\hline Anthalona harti Van Damme, Sinev and Dumont 2011 & + & + & - & $\mathrm{R}$ \\
\hline Graptoleberis testudinaria (Fischer, 1854) s.lat & + & + & - & $\mathrm{R}$ \\
\hline Kurzia (Rostrokurzia) longirostris (Daday, 1898) & + & + & + & MA \\
\hline Kurzia (Rostrokurzia) brevilabris (Rajapaksa and Fernando, 1986) & + & + & - & $\mathrm{R}$ \\
\hline
\end{tabular}

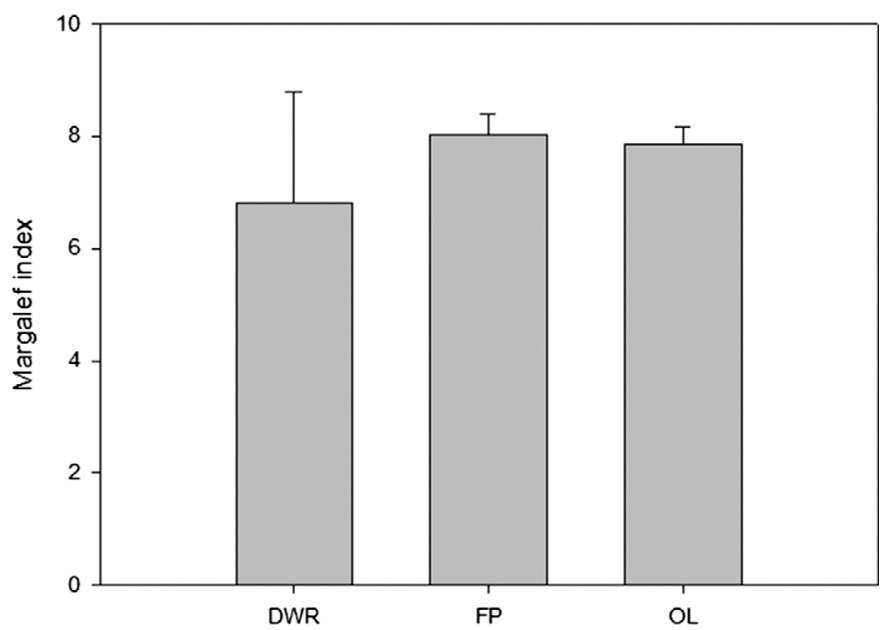

Fig. 2. Species richness (Margalef's index) of the floodplain wetlands of Subansiri (DWR: deep water rice field; FP: floodplain lake; OL: oxbow lake).

cladoceran fauna (Michael and Sharma, 1988) while Bosminidae and Daphniidae are subdominant groups in these climatic regions (Lansac-Tôha et al., 2009; Ghidini et al., 2009; Shah and Pandit, 2013). The representativeness of Chydoridae in number of species is a common pattern in many regions of the world and the results observed herein are often reported for other locations in East Asia (Sinev and Korovchinsky, 2013; Kotov et al., 2013). Regarding water bodies in the Indian subcontinent, Chydoridae also seems to have high richness (Sharma and Sharma, 2008; Shah and Pandit, 2013; Sharma et al., 2015). This can be partly explained by the specializations of Chydoridae to exploit many microenvironments and anti-predation refuges provided by the vegetation (Jones et al., 2000; Forró et al., 2008). Besides, diverse assemblages of cladoceran in floodplain wetlands might be related to factors such as climatic conditions, depth of water bodies and the perenniality of wetlands (Sa-ardrit and Beamish, 2005; Sousa et al., 2013).

The faunal similarity was higher between the OL and FP, which was of approximately $80 \%$. Both environments are shallow and are greatly influenced by rivers through channels during the rainy season. In many cases, changes in the community structure of aquatic invertebrates in floodplains are driven by hydrological dynamics (Dias et al., 2016, 2017). Faunal homogenization can be a plausible result when species from lotic and lentic systems are combined in the same habitat (Bozelli et al., 2015). Thus, it is possible that the hydrological dynamics, with lotic systems being seasonally connected with lentic environments, may result in faunal similarities between OL and FP. Regarding the DWR, species composition was quite different from OL and FP due to the prevalence of slow flowing water and macrophytes (similarity approximated to $50 \%$ ). The Margalef index results also indicate spatial variations of cladoceran communities (Fig. 2). Both wetlands presented a high number of rare species (Tab. 1), such as species with low abundances (Fig. 3). The number of rare species characterizes the numerical structure of communities (Warwick et al., 1987; Aoki, 1995) and explains the pattern of planktonic assemblages (Hwang et al., 2009).

The spring and summer seasons were found to be the most favourable periods for the population growth of cladocerans. Higher densities during summer-spring months was associated with an abundance of small-sized cladocerans such as 

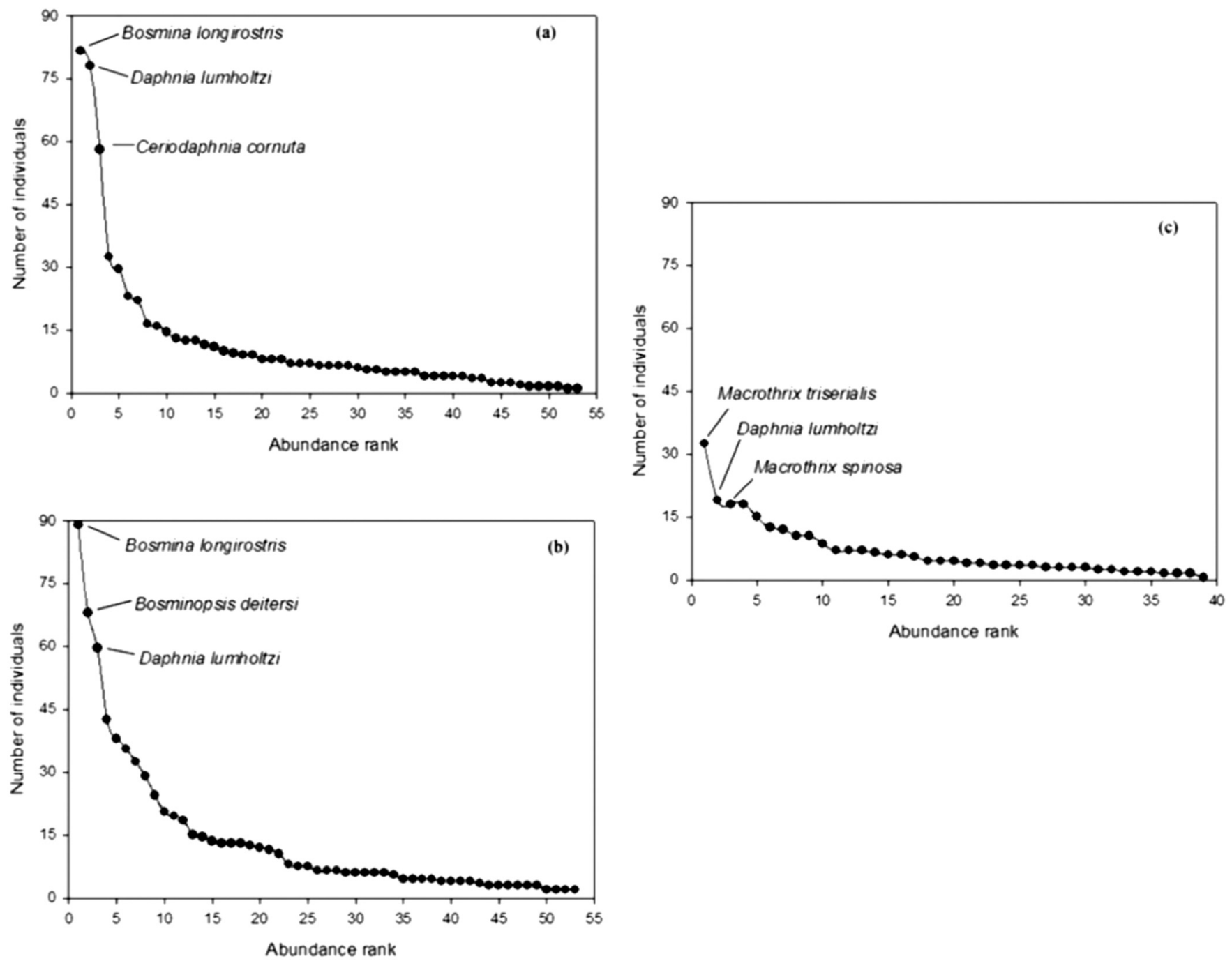

Fig. 3. Species abundance curves. (a) Floodplain lake. (b) Oxbow lake. (c) Deep water rice field.

Chydorus, Alona, Dadaya, Ephemeroporus, Coronatella, Kurzia and so on. Higher temperatures favour the development of small species and suppress the development of large species (Gillooly et al., 2002; Feniova et al., 2013). The summer peak might be related to multiple factors, including favourable temperature, high nutrient conditions, food availability and hatching of resting eggs (Dejen et al., 2004; Okogwu, 2010). The observed species richness was in conformity with the observation of Sharma et al. (2015) in the floodplain lakes of the Majuli River island. The species composition and density of cladoceran in floodplain ecosystems were probably regulated by temperature, food availability and their intrinsic interactions.

The cladoceran fauna of the Subansiri River floodplain wetlands were represented by biogeographically important taxa such as Diaphanosoma dubium. Latonopsis australis, Simocephalus mixtus, Chydorus sphaericus, C. parvus, Chydorus cf. ovalis, Alonella clathratula, Pleuroxus cf. denticulatus, Picripleuroxus cf. quasidenticulatus, C. macronyx, Coronatella anodonta and Kurzia (Rostrukurzia) brevilabris. Of these,
S. mixtus and P. cf. denticulatus comprises new records for the Assam state.

Regarding the Sididae species, D. dubium (Manuilova, 1964) (Fig. 4, a-d) is an Asian tropical-subtropical species originally described from Russia. It was treated as Diaphanasoma leuchtenbergianum (Chiang and Du, 1979) until its description from India (Kanduru, 1981), Bangladesh (Hossain, 1982) and further records from India (Fernando and Kanduru, 1984). It was reported from East, South-East and South Asia (Korovchinsky, 1998). It is distributed in Assam, Central India and Delhi within India. L. australis Sars, 1888 (Fig. 4, e-g) was described from Australia; however, 12 setae were illustrated on dorsal ramus, which leads to describing it as Latonopsis occidentalis by Birge (1892) from Wincinson and as Latonopsis breviremis by Daday (1905). This is apparently a group of cryptic species (Korovchinsky, 2004). It is a common and widely distributed tropicopolitan species in South-East Asia (Kotov et al., 2013). It is reported from Andaman \& Nicobar Islands, Goa, Karnataka, Maharashtra, Rajasthan, Tamil Nadu, Tripura, Assam and West Bengal within India. 

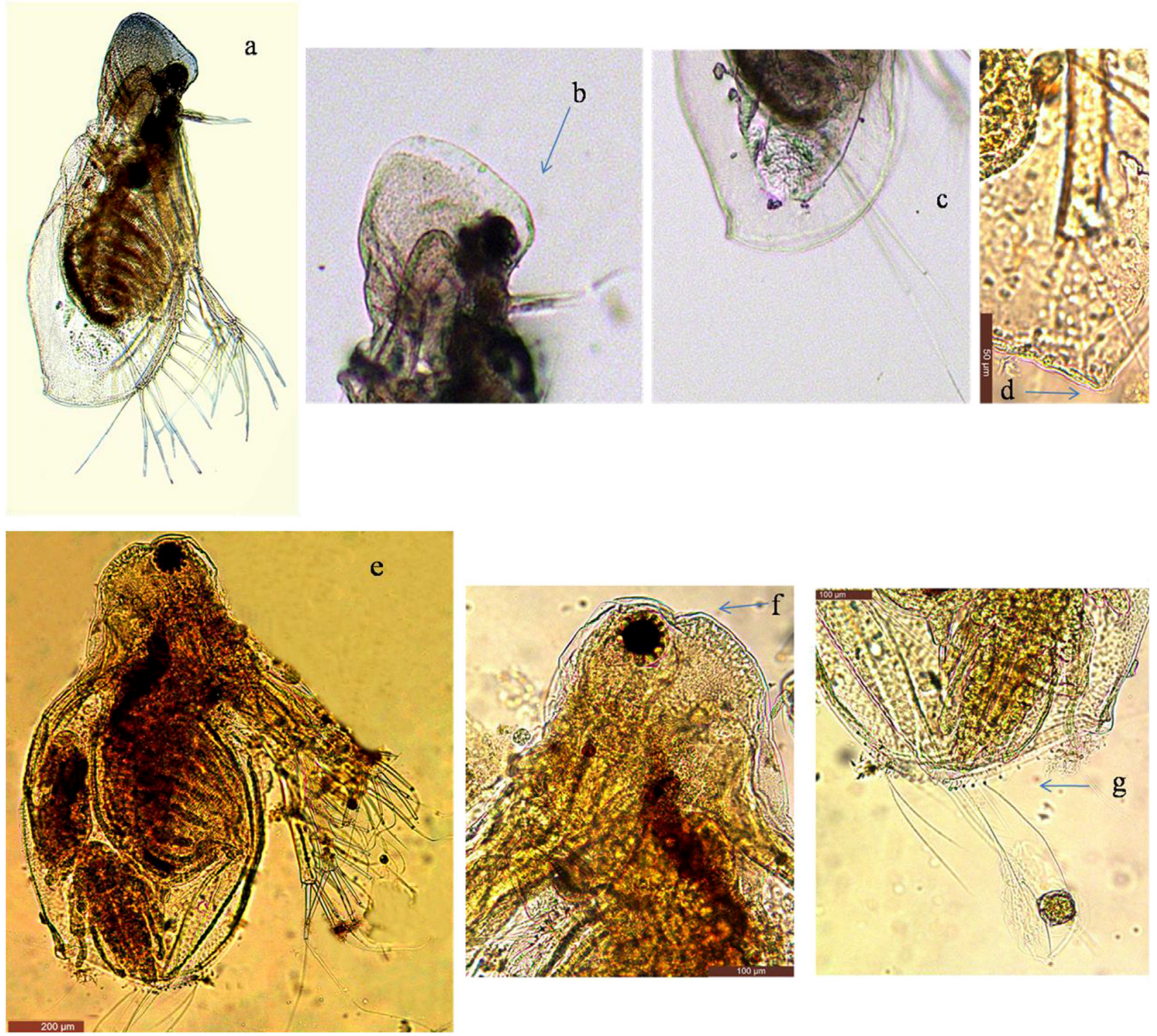

Fig. 4. Cladocerans (Sididae) from the Subansiri floodplain wetlands. (a-d) Diaphanosoma dubium: (a) lateral view; (b) head; (c) postabdomen with postabdominal setae; (d) posterodorsal corner; (e-g) Latonopsis australis: (e) lateral view; (f) head; (g) posterior protuberance with setae. Scale bars $=50-200 \mu \mathrm{m}$.

The Daphniidae S. mixtus Sars, 1903 (Fig. 5, a-e) was originally described from Mongolia by Sars (1903). It is a cosmopolitan species distributed in Asia, Eastern Europe, Northern Africa and North America (Orlova-Bienkowskaja, 2001). The S. mixtus is a new record for the state of Assam in addition to the reports of distribution from Manipur and Meghalaya within India.

In Chydoridae, Chydorus sphaericus (Müller, 1776) (Fig. 6, a-e) was originally described from Denmark. The C. sphaericus complex remains morphologically unrevised. The C. sphaericus complex is considered cosmopolitan (Elmoor-Loureiro, 1997; Sharma and Kotov, 2015), but its true diversity and biogeographical patterns remain unknown because of the taxonomical difficulties (Belyaeva and Taylor, 2009). This complex comprises a species assemblage with little morphological (Belyaeva, 2003) but significant molecular divergences (Belyaeva and Taylor, 2009; Kotov et al., 2016). This pattern of cryptic diversity can be expected in Chydorid species groups (Frey, 1987; Van Damme et al., 2010). It is distributed in Andhra Pradesh, Assam, Bihar, Jammu \& Kashmir, Jharkhand, Karnataka, Kerala, Madhya Pradesh, Maharashtra, Manipur, Meghalaya, Mizoram, Rajasthan, Tamil Nadu, Tripura, Uttarakhand and West Bengal within India. C. parvus (Daday, 1898) (Fig. 6, f-i) was originally described from Sri Lanka. It is widespread in the Oriental zone (Idris, 1983; Maiphae et al., 2005) and one of the most common Chydorus species in India (Chatterjee et al., 2013). It is common in the Ethiopian and Indo-Malayan regions (Smirnov, 1996). It is distributed in Andaman \& Nicobar Islands, Andhra Pradesh, Jharkhand, Kerala, Meghalaya, 

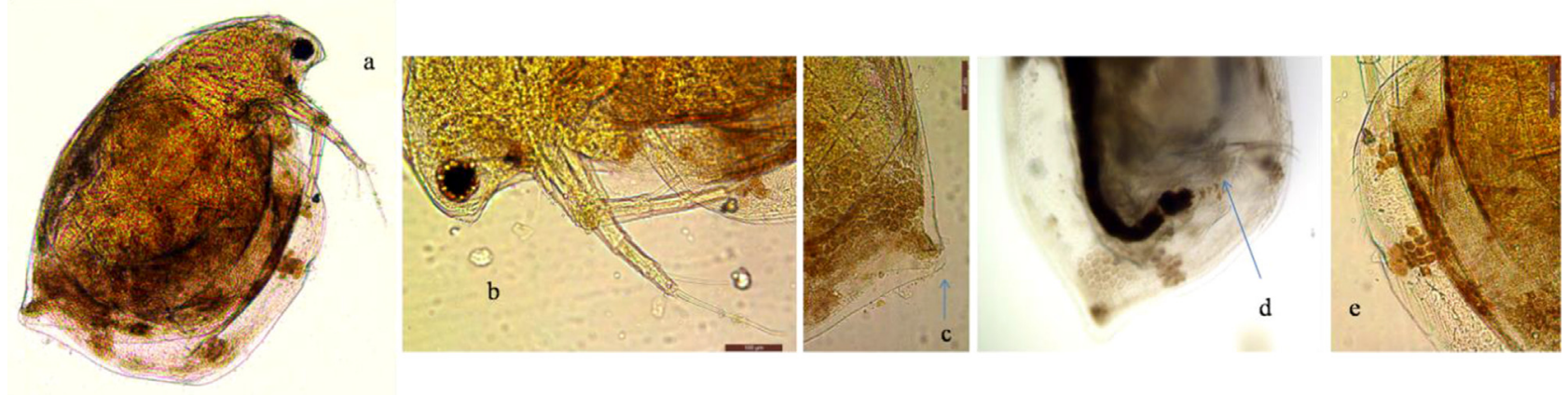

Fig. 5. Cladoceran (Daphniidae) from the Subansiri floodplain wetlands. (a-e) Simocephalus mixtus: (a) lateral view; (b) head with antennules and antennae; (c) posterior protuberance; (d) postabdomen; (e) ventral margin. Scale bars $=50-200 \mu \mathrm{m}$.

Punjab, Tamil Nadu, West Bengal and Assam within India. Chydorus cf. ovalis Kurz, 1874 (Fig. 6, j-1) was described from the Czech Republic and distributed throughout the Palaearctic region (Smirnov, 1976). It is distributed in Rajasthan, Jammu \& Kashmir and Assam within India.

A. clathratula Sars, 1896 (Fig. 6, m-p) was originally described from Australia and was formerly treated as a subspecies of Alonella excisa by Smirnov (1971). Smirnov (1996) subsequently revived its specific status based on an elongated body and postabdomen, as well as a different distributional range. It occurs in Australia, the Neotropical and Ethiopian regions, and Java (Smirnov, 1996; Van Damme and Dumont, 2010). It is quite common in the Oriental zone (Sanoamuang, 1998; Maiphae et al., 2005; Tanaka and Ohtaka, 2010) while showing a cosmopolitan distribution. A. clathratula was apparently overlooked in studies in India, until its reports from Bihar (Sharma and Sharma, 2001), Assam (Sharma and Sharma, 2008, 2010) and Meghalaya (Sharma, 2010). It is distributed in Assam, Bihar, Kerala, Manipur and Meghalaya within India.

Pleuroxus cf. denticulatus Birge 1879, (Fig. 6, q-t) was described from North America by Birge (1879) and redescribed by Hudec and Illyova (1998) from Slovakia. It was reported from Italy (Margaritora, 1983), the Iberian Peninsula (Alonso, 1996), France (Amoros, 1984), Belgium (Dumont, 1989), England (Scourfield, 1907), India (Michael and Sharma, 1988), Central Africa (Kórinek, 1984) and Australia (Smirnov and Timms, 1983). It is Holarctic in distribution and other records should be reconsidered (Smirnov, 1996). It is a new record for the Assam state in addition to its distribution in Andaman \& Nicobar Islands, Delhi, Goa, Jammu \& Kashmir, Karnataka, Maharashtra, Uttarakhand and West Bengal.

Picripleuroxus cf. quasidenticulatus (Smirnov, 1996), (Fig. 7, a-d) was originally described from Australia by Smirnov (1996). It was redescribed by Sinev and Sanoamuang (2013) from specimens of Thailand, Vietnam and Russia. It was reported from Iraq and Argentina (Smirnov, 1996), Thailand (Maiphae et al., 2008) and Vietnam (Sinev and Korovchinsky, 2013). It was reported from India by Sharma et al. (2015) and we have confirmed its distribution in the Indian subregion within the Oriental region. It is reported only from Assam within India.

C. macronyx (Daday, 1898) (Fig. 7, e-i) was originally described from Sri Lanka by Daday (1898) as Alona macronyx. Brehm (1933) included it as Alonella macronyx in the species list of the Indo-Malaysian region. Smirnov (1974) assigned it to the genus Indialona, further Sinev and Kotov (2012) allocated it to the genus Celsinotum. The first Indian report of A. macronyx was referred to as Indialona jabalpurensis, a new species described by Rane (1983) from Madhya Pradesh, which was designated as a synonym of $A$. macronyx by Sharma and Sharma (1990) and reported as C. macronyx, a new record from Assam by Sharma and Sharma (2012). It is an oriental species widely found in India, Sri Lanka, Indo-China, Indonesia, Philippines, Vietnam and South China. It is distributed in Assam, Madhya Pradesh, Maharashtra and Meghalaya within India.

Coronatella anodonta (Daday, 1905) (Fig. 7, j-m) was described by Daday (1905) from Paraguay as Alona anodonta. Rajapaksa and Fernando (1982b) recorded a tuberculated form of A. anodonta as Alona. cf. anodonta from Sri Lanka. Van Damme et al. (2010) proposed to allocate A. anodonta to the genus Coronatella. Sharma and Sharma (2011) reported it as Coronatella anodonta from Meghalaya, India. Chatterjee et al. (2013) emphasize the need of a revision of this species, given that it is easily confused with Coronatella rectangula. It was reported from Assam, Meghalaya and Tamil Nadu within India.

Kurzia (Rostrokurzia) brevilabris (Rajapaksa and Fernando, 1986) (Fig. 7, n-q) is an oriental endemic, which was originally described from Thailand (Rajapaksa and Fernando, 1986b), while Hudec (2000) placed it to the subgenus Rostrokurzia. It was recently reported from Northeast India by Sharma and Sharma (2012) and the record of this species in the Subansiri floodplain wetlands confirms its distribution within the South Asian region. It was also reported from Sri Lanka, Philippines Iraq and Argentina (Smirnov, 1996), Thailand (Maiphae et al., 2008) and Vietnam (Korovchinsky, 2013). It is distributed in Assam and Uttarakhand within India.

The occurrences of these species could reveal links of the cladoceran fauna of India to those of South-East Asia and other regions of the world. Furthermore, the documentation of these species from the Subansiri floodplain wetland has confirmed their distribution in Indian River floodplain wetlands. Documentation of the Australasian Disparalona caudata, the Indo-Chinese Flavalona cheni, and the Oriental $C$. reticulata in the Subansiri floodplain wetlands has confirmed the occurrence of these important taxa in India. Among the species documented, D. dubium was reported as an Asian tropical-subtropical species, while C. macronyx, Chydorus 

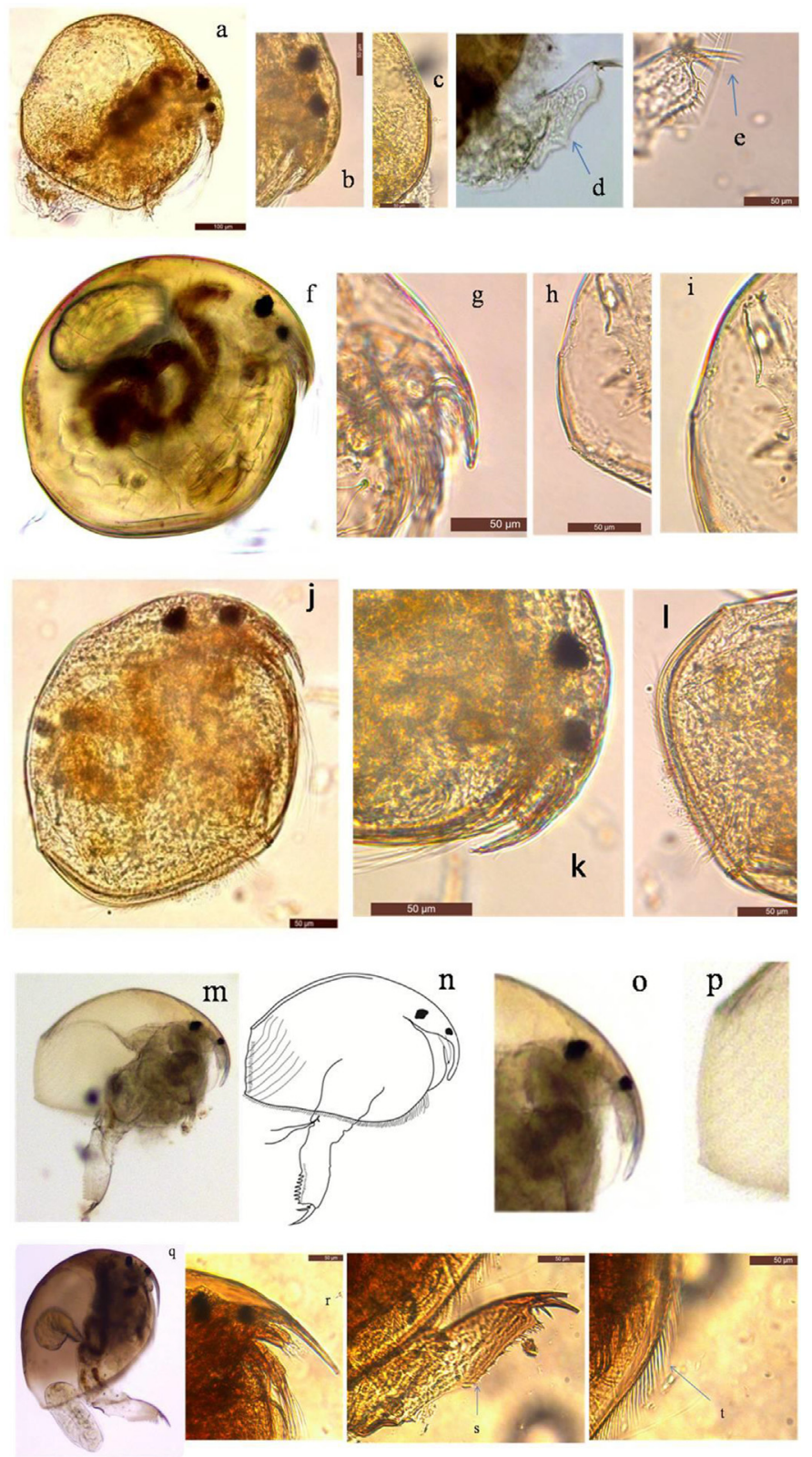

Fig. 6. Cladocerans (Chydoridae) from the Subansiri floodplain wetlands. (a-e) Chydorus sphaericus: (a) lateral view; (b) rostrum and antennules; (c) posterior margin; (d) postabdomen; (e) claw; (f-i) C. parvus: (f) lateral view; (g) rostrum and labrum; (h) posteroventral margin; (i) posterodorsal margin; (j-1) Chydorus ovalis: (j) lateral view; (k) rostrum and antennules; (l) posterior margin; $(\mathrm{m}-\mathrm{p})$ A. clathratula: (m) lateral view; (n) line drawing; (o) rostrum and antennules; (p) posterior margin; (q-t) Pleuroxus cf. denticulatus: (q) lateral view; (r) rostrum, antennules and labrum; (s) postabdomen; (t) ventral margin. Scale bars $=50-200 \mu \mathrm{m}$.

angustirostris and Kurzia (Rostrukurzia) brevilabris were reported as oriental species (Maiphae et al., 2008).

Many of the species such as Daphnia lumholtzi, Latonopsis australis, Bosminopsis deitersi, Ceriodaphnia cornuta, M. spinosa, Chydorus sphaericus, Ilyocryptus spinifer, Kurzia longirostris, A. clathratula, Flavalona cf. costata, Coronatella cf. acuticostata, Pleuroxus cf. denticulatus, Euryalona orientalis, Simocephalus serrulatus and Picripleuroxus cf. quasidenticulatus have been reported to show broad geographical distributions (Egborge et al., 1994; Davidson et al., 2000, Chiambeng and Dumont, 2004). Species such as Coronatella anodonta, Simocephalus serrulatus, Camptocercus uncinatus, C. ventricosus, Notoalona globulosa, Graptoleberis testudinaria, Coronatella cf. acuticostata, A. clathratula, Alona guttata and Notoalona globulosa were also found in the study area. They exhibit discontinuous distribution throughout India (Sharma and Sharma, 2014). Meanwhile, Latonopsis australis, Bosmina longirostris, Moinodaphnia macleayi, Macrothrix triserialis, 

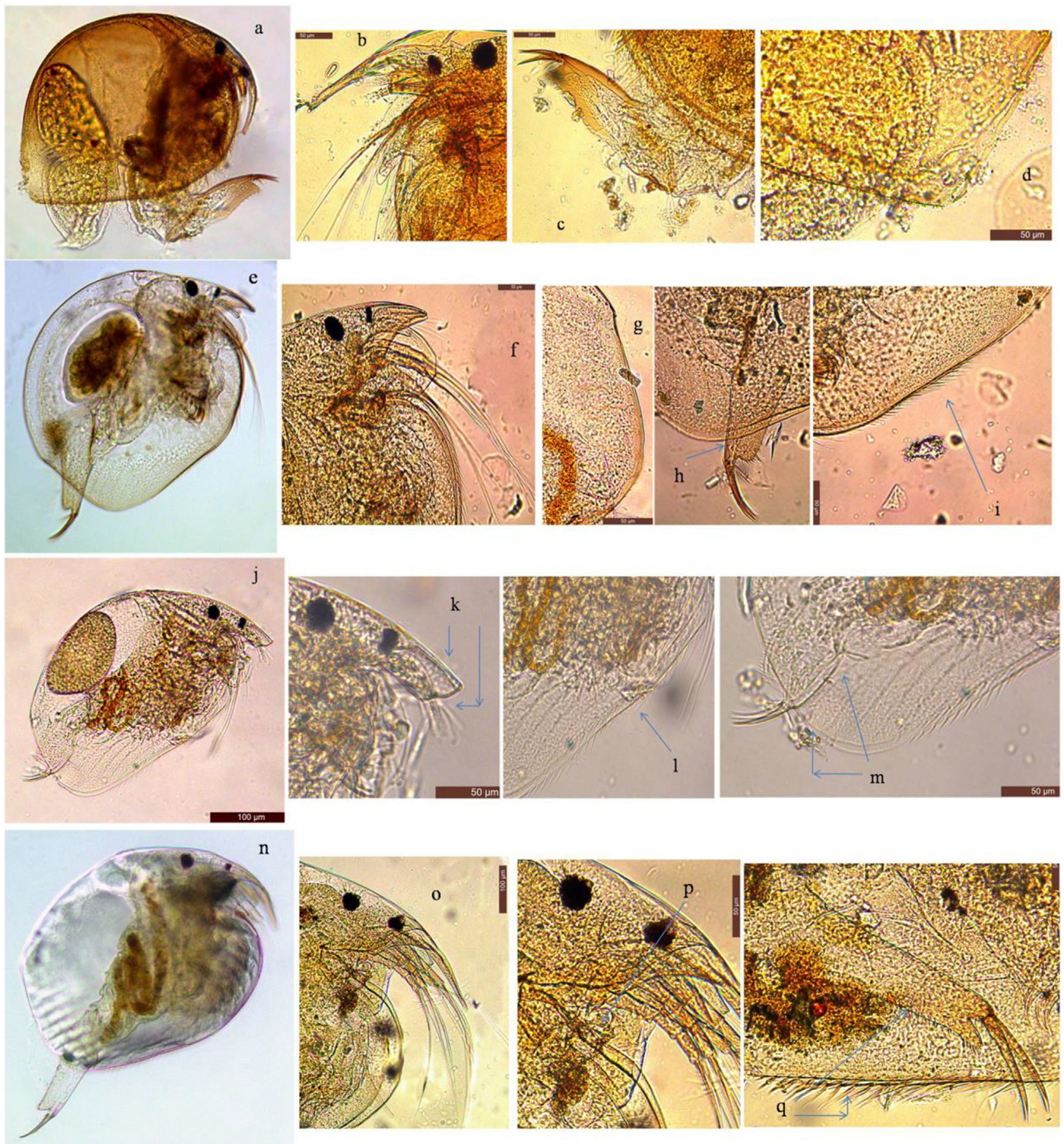

Fig. 7. Cladocerans (Chydoridae) from the Subansiri floodplain wetlands. (a-d) Picripleuroxus cf. quasidenticulatus: (a) lateral view; (b) rostrum, antennules and antennae; (c) postabdomen; (d) posterior corner; (e-i) C. macronyx: (e) lateral view; (f) rostrum, antennules, antennae and labrum; $(\mathrm{g})$ posterior margin; (h) postabdomen; (i) ventral margin; $(\mathrm{j}-\mathrm{m})$ Coronatella anodonta: (j) lateral view; (k) rostrum and antennules; (l) ventral margin; (m) postabdomen and posterior margin; (n-q) Kurzia (Rostrokurzia) brevilabris: (n) lateral view; (o) rostrum, antennules and antennae; (p) labral keel and labrum; (q) postabdomen and ventral margin. Scale bars $=50-200 \mu \mathrm{m}$.

M. spinosa, Guernella raphaelis, Kurzia (Rostrokurzia) longirostris, Dadaya macrops, C. eurynotus, C. ventricosus, C. parvus and Flavalona cheni belong to the group of circumtropical species (Padhye and Dumont, 2015), also documented from similar habitats elsewhere. The cladoceran fauna of the Subansiri floodplain wetlands revealed tropical characteristics with cosmopolitan, cosmotropical and oriental elements. The rich faunal composition might be attributed to the diversification of habitats and ecological niches provided by macrophytes (Dejen et al., 2004). 


\section{Conclusion}

The cladoceran fauna of the Subansiri River floodplain wetland is comprised of cosmopolitan, cosmotropical and oriental elements. Faunal composition reveals the characteristics of tropical Cladocera with the occurrence of biogeographically interesting elements. The occurrences of several biogeographically important species highlight the importance of the biodiversity of Subansiri River floodplain wetlands. The records of globally interesting species contribute to the information on cladoceran biogeography. Even though baseline information gathered in the present study contributes with valuable information to the diversity and distribution of cladoceran in the Indian floodplain wetlands, we still do not possess enough information to draw conclusions concerning patterns in species richness. Further extensive sampling and continuous systematic efforts with recent morphological techniques and standards will definitely increase the total number of species reported for the region. Despite the presence of taxonomic uncertainties regarding certain species (Chatterjee et al., 2013), the distribution of the 55 species in the wetlands clearly supports the validity of other reports of certain species of Cladocera in India.

Acknowledgements. We sincerely thank Dr. Sameer Padhye for his guidance and help in the confirmation of species identification. We would also like to acknowledge Dr. Achom Darshan Singh for his generous support for the accomplishment of this work.

\section{References}

Alonso M. 1996. Crustacea, Branchiopoda. Fauna Iberica 7, Museo Nacional de Ciencias Naturales, CSIC, Madrid, 486 p.

Amoros C. 1984. Crustaćes Cladoćeres. Introduction pratique à la systématique des organismes des eaux continentales françaises. Bull Soc Linn 53: 72-143.

Aoki I. 1995. Diversity and rank-abundance relationship concerning biotic compartments. Ecol Model 82: 21-26.

Belyaeva M. 2003. Littoral Cladocera (Crustacea: Branchiopoda) from the Altai mountain lakes, with remarks on the taxonomy of Chydorus sphaericus (O.F. Muller, 1776). Arthropoda Sel 12: 171-182.

Belyaeva M, Taylor DJ. 2009. Cryptic species within the Chydorus sphaericus species complex (Crustacea: Cladocera) revealed by molecular markers and sexual stage morphology. Mol Phylogenet Evol 50: 534-546.

Birge EA. 1879. Notes on Cladocera. Trans Wisconsin Acad Sci Arts Lett 4: 77-109.

Birge EA. 1892. List of Crustacea Cladocera from Madison, Wisconsin. Trans Wisconsin Acad Sci Arts Lett 8: 379-398.

Bozelli RL, Thomaz SM, Padial AA, Lopes PM, Bini LM. 2015. Floods decrease zooplankton beta diversity and environmental heterogeneity in an Amazonian floodplain system. Hydrobiologia 753: 233-241.

Brehm V. 1933. Die Cladoceren der Deutschen Limnologischen Sunda-Expedition. Arch Hydrobiol (Suppl) 11: 631-771.

Brower JE, Zar JH. 1977. Field and laboratory methods for general ecology. Dubuque, IA: WMC Brown Co. Publisher, 124 p.

Chatterjee T, Kotov AA, Van Damme K, Chandrasekhar SVA, Padhye S. 2013. An annotated checklist of the Cladocera (Crustacea: Branchiopoda) from India. Zootaxa 3667: 1-89.
Chiambeng GY, Dumont HJ. 2004. The genus Pleuroxus Baird, 1843 (Crustacea: Anomopoda: Chydoridae) in Cameroon, Central-West Africa. Ann Limnol - Int J Lim 40: 211-229.

Chiang SC, Du NS. 1979. Freshwater Cladocera. Fauna Sinica. Peking: Crustacea Science Press, 297 p. (in Chinese).

Daday E. 1898. Mikroskopische Süsswasserthiere aus Ceylon. Természetrajzi Füzet 21: 1-123.

Daday E. 1905. Untersuchungen uber die Süsswasser-Mikrofauma Paraguays. Zoologica 18: 1-374.

Dajoz R. 1983. Ecologia Geral. São Paulo: Vozes, EDUSP, 472 p.

Davidson NL, Jr, Kelso WE, Rutherford DA. 2000. Characteristics of cladoceran and copepod communities in floodplain habitats of the Atchafalaya River Basin. Hydrobiologia 435: 99-107.

Dejen E, Jacoubs V, Nagelkerk AJ, Sibbing FA. 2004. Temporal and spatial distribution of micro crustacean zooplankton in relation to turbidity and other environmental factors in a large tropical lake (Lake Tana, Ethiopia). Hydrobiologia 513: 39-49.

Dias JD, Simões NR, Meerhoff M, Lansac-Tôha FA, Velho LFM, Bonecker CC. 2016. Hydrological dynamics drives zooplankton metacommunity structure in a Neotropical floodplain. Hydrobiologia 781: 109-125.

Dias JD, Miracle MR, Bonecker CC. 2017. Do water levels control zooplankton secondary production in Neotropical floodplain lakes? Fundam Appl Limnol 190: 49-62.

Dodson SI, Frey DG. 2001. Cladocera and other Branchiopoda. In: Thorp JH, Covich AP, eds. Ecology and Classification of North American Freshwater Invertebrates. San Diego: Academic Press, pp. 849-913.

Dumont HJ, Silva-Briano M. 2000. Karualona n. gen. (Anomopoda: Chydoridae), with a description of two new species, and a key to all known species. Hydrobiologia 435: 61-82.

Dumont HJ, Silva-Briano M, Babu KKS. 2002. A re-evaluation of the Macrothrix roseatriserialis group, with the description of two new species (Crustacea: Anomopoda: Macrothricidae). Hydrobiologia 467: 1-44.

Egborge ABM, Onwudinjo CC, Chigbu PC. 1994. Cladocera of coastal rivers of west Nigeria. Hydrobiologia 272: 39-46.

Elmoor-Loureiro LMA. 1997. Manual de Identificação de Cladóceros Límnicos do Brasil. Brasília Universa, 156 p.

Elmoor-Loureiro LMA. 2000. Brazilian cladoceran studies: where do we stand? Nauplius 8: 117-131.

Feniova IYu, Palash AL, Razlutskij VI, Dzialowski AR. 2013. Effects of temperature and resource abundance on small and large-bodied cladocerans: community stability and species replacement. OJE 3: 164-171.

Fernando CH, Kanduru A. 1984. Some remarks on the latitudinal distribution of Cladocera on the Indian subcontinent. Hydrobiololgia 113: 69-76.

Forró L, Korovichinsky NM, Kotov AA, Petrusek A. 2008. Global diversity of cladocerans (Cladocera; Crustacea) in freshwater. Hydrobiologia 595: 177-184.

Frey DG. 1959. The taxonomic and phylogenetic significance of the head pores of the Chydoridae (Cladocera). Int Rev Ges Hydrobiol 44: 27-50.

Frey DG. 1982a. Questions concerning cosmopolitanism in Cladocera. Arch Hydrobiol 93: 484-502.

Frey DG. 1982b. Relocation of Chydorus barroisi and related species (Cladocera, Chydoridae) to a new genus and description of two new species. Hydrobiologia 86: 231-269.

Frey DG. 1987. The taxonomy and biogeography of the Cladocera. Hydrobiologia 145: 5-17.

Ghidini AR, Serafim-Júnior M, Perbiche-Neves G, Brito LD. 2009. Distribution of planktonic cladocerans (Crustacea: Branchiopoda) 
of a shallow eutrophic reservoir (Paraná State, Brazil). Pan-Am J Aquat Sci 4: 294-305.

Gillooly JF, Charnov EL, West GB, Savage VM, Brown JH. 2002. Effects of size and temperature on developmental time. Nature 417: $70-73$.

Hossain A. 1982. A taxonomical study of zooplankton (Rotifera, Cladocera \& Copepoda) of Bangladesh. M. Sc. thesis, University of Waterloo, Ontario, Canada, 284 p.

Hudec I. 2000. Subgeneric differentiation within Kurzia (Crustacea: Anomopoda: Chydoridae) and a new species from Central America. Hydrobiologia 421: 165-178.

Hudec I, Illyova M. 1998. Pleuroxus denticulatus (Crustacea: Anomopoda: Chydoridae): a new invader in the Danube Basin. Hydrobiologia 368: 65-73.

Hwang JS, Souissi S, Dahms HU, Tseng LC, Schmitt FG, Chen QC. 2009. Rank-abundance allocations as a tool to analyze planktonic copepod assemblages of the Danshuei River Estuary (Northern Taiwan). Zool Stud 48: 49-62.

Idris BAG. 1983. Freshwater zooplankton of Malaysia (Crustacea: Cladocera). Pertanian, Malaysia: Perenbit University, 153 p.

Illyova M, Nemethova D. 2005. Long-term changes in cladoceran assemblages in the Danube floodplain area (Slovak-Hungarian stretch). Limnologica 35: 274-282.

Jones JI, Moss B, Eaton J, Young JO. 2000. Do submerged aquatic plants influence periphyton community composition for the benefit of invertebrate mutualists? Freshw Biol 43: 591-604.

Kanduru AI. 1981. The Cladocera (Crustacea: Branchiopoda) of the Indian subcontinent and their latitudinal distribution. M. Sc. thesis, Waterloo, Ontario, Canada, 313 p.

Khan MA. 1987. Observations on zooplankton composition, abundance and periodicity in two floodplain lakes of Kashmir Himalayan valley. Acta Hydrochim Hydrobiol 15: 174-176.

Kiss A. 2004. Long-term changes of Crustacean (Cladocera, Ostracoda, Copepoda) assemblages in Szigetkoz floodplain area (Hungary) 1991-2002. Int Assoc Danube Res 35: 2-7.

Kiss A, Scholl K. 2009. Checklist of the Crustacea (Cladocera, Ostracoda, Copepoda) fauna in the active floodplain area of the Danube (18431806, 1669 and 1437-1489rkm). Opusc Zool Budapest 40: 27-39.

Korovchinsky NM. 1997. On the history of studies on cladoceran taxonomy and morphology, with emphasis on early work and causes of insufficient knowledge of the diversity of the group. Hydrobiologia 360: 1-11.

Korovchinsky NM. 1998. Revision of Diaphanosoma modiglianiD. dubium species group (Crustacea: Ctenopoda: Sididae) with a description of a new species from tropical Asia. Hydrobiologia 361: 113-123.

Korovchinsky NM. 2002. Description of two new species of Diaphanosoma Fischer, 1850 (Crustacea, Branchiopoda, Sididae) from the United States and Canada and species richness of the genus in North America. Hydrobiologia 489: 45-54.

Korovchinsky NM. 2004. Cladocerans of the Order Ctenopoda of the World Fauna (Morphology, Systematics, Ecology, Biogeography). Moscow: KMK Press, 410 p.

Korovchinsky NM. 2013. Cladocera (Crustacea: Branchiopoda) of South East Asia: history of explorations, taxon richness and notes on zoogeography. J Limnol 72: 109-124.

Kórinek V. 1984. Cladocera. Hydrobiogical survey of the Lake Bangeulu, Luapula river Basin, Cercle Hydrobiologique de Bruxelles, 117 p.

Kořinek V, Saha RK, Bhattacharya T. 1999. A new member of the subgenus Sinobosmina Lieder, 1957: Bosmina tripurae sp. nov. (Crustacea, Cladocera) from South Asia. Hydrobiologia 392: $241-247$.
Kotov AA. 1999. Redescription of Macrothrix tripectinata Weisig, 1934 (Anomopoda, Branchiopoda), with a discussion of some features rarely used in the systematics of the genus. Hydrobiologia 403: 63-80.

Kotov AA. 2008. Importance of male and ephippial female characters for differentiating three Palaearctic species of Macrothrix Baird, 1843 (Cladocera: Anomopoda), with a redescription of Macrothrix dadayi Behning, 1941. Ann Limnol - Int J Lim 44: 45-61.

Kotov AA. 2011. Crustacea-Cladocera check list. Freshwater Animal Diversity Assessment (FADA) Project. Available at http://fada. biodiversity.be/CheckLists/Crustacea-Cladocera.pdf (accessed 9.2012).

Kotov AA, Sinev AY. 2011. Cladocera (Crustacea, Branchiopoda) from the Zeya River basin (Amur Region, Russia) 2. Descriptions of new taxa. Zool Zhurnal 90: 272-284.

Kotov AA, Ishida S, Taylor DJ. 2009. Revision of the genus Bosmina Baird, 1845 (Cladocera: Bosminidae), based on evidence from male morphological characters and molecular phylogenies. Zool $J$ Linn Soc 156: 1-56.

Kotov AA, Jeong HG, Lee W. 2012. Cladocera (Crustacea: Branchiopoda) of the south-east of the Korean Peninsula, with twenty new records for Korea. Zootaxa 3368: 50-90.

Kotov AA, Van Damme K, Bekker EI, Siboualipha S, Silva-Briano M, Ortiz AA, De La Rosa RG, Sanoamuang L. 2013. Cladocera (Crustacea: Branchiopoda) of Vientiane province and municipality, Laos. J Limnol 72: 81-108.

Kotov AA, Karabanov DP, Bekker EI, Neretina TV, Taylor DJ. 2016. Phylogeography of the Chydorus sphaericus group (Cladocera: Chydoridae) in the Northern Palearctic. PLoS One 11: $1-20$

Kurz W. 1874. Dodekas neuer Cladoceren mebst einer kurzen Übersicht der Cladocerenfauna Böhmens. Sitzungsberichte der Akademie der Wissenschaften in Wien, Abt. I. Mineralogie, Biologie. Erdkunde verwandte Wissenschaft 70: 7-88.

Lansac-Tôha FA, Bonecker CC, Velho LFM, Simões NR, Dias JD, Alves GM, Takahashi EM. 2009. Biodiversity of zooplankton communities in the Upper Paraná River floodplain: interannual variation from long-term studies. Braz J Biol 69: 539-549.

Maiphae S, Pholpunthin P, Dumont HJ. 2005. Species richness of the Cladocera (Branchiopoda: Anomopoda and Ctenopoda) in southern Thailand, and its complementarity with neighboring regions. Hydrobiologia 537: 147-156.

Maiphae S, Pholpunthin P, Dumont HJ. 2008. Taxon richness and biogeography of the Cladocera (Crustacea: Ctenopoda, Anomopoda) of Thailand. Ann Limnol - Int J Lim 44: 33-43.

Manuilova EF. 1964. The cladocerans fauna of the USSR. Opredeliteli po faune SSSR 88: 1-327.

Margaritora F. 1983. Cladoceri (Crustacea: Cladocera) Guide per il Riconoscimento delle specie Animali delle acque interne Italiane 22. Consiglio Nazionale Delle Ricerche AQ/1/197, Verona, $169 \mathrm{p}$.

Michael RG, Sharma BK. 1988. Indian Cladocera (Crustacea: Branchiopoda: Cladocera). Fauna of India and adjacent countries series, Zoological Survey of India, Calcutta, 262 p.

Müller OF. 1776. Zoologiae Danicae Prodromus, seu Animalium Daniae et Norvegiae Indigenarum Characteres, nomina et synonyma imprimis popularium. Havniae: Typis Hallageriis, 274 p.

Okogwu IO. 2010. Seasonal variations of species composition and abundance of zooplankton in Ehoma Lake, a floodplain lake in Nigeria. Rev Biol Trop 58: 171-182. 
Orlova-Bienkowskaja MY. 2001. Daphniidae: genus Simocephalus. Guides to the identification of the microinvertebrates of the continental waters of the world 17. Leyden: Backhuys, $130 \mathrm{p}$.

Padhye SM, Dumont HJ. 2015. Species richness of cladoceran (Crustacea: Branchiopoda) in the Western Ghats of Maharashtra, Goa (India) with biogeographical comments. J Limnol 74: 182-191.

Padhye SM, Van Damme K. 2015. Note on Kurzia (Kurzia) latissima (Kurz, 1875) (Branchiopoda: Anomopoda: Chydoridae) from India. Zootaxa 3980: 293-297.

Pascual JAF, Rizo EZC, Han B, Dumont HJ, Papa RDS. 2014. Taxonomy and distribution of four Cladoceran families (Branchiopoda: Cladocera: Moinidae, Bosminidae, Chydoridae and Sididae) in Philippine inland waters. Raffles Bull Zool 62: 771-794.

Raghunathan MB, Kumar S. 2003. Checklist of Indian Cladocera (Crustacea). Zoos Print J 18: 1180-1182.

Rajapaksa R, Fernando CH. 1982a. The first description of the male and ephippial female of Dadaya macrops (Daday, 1898) (Cladocera, Chydoridae), with additional notes on this common tropical species. Can J Zool 60: 1841-1850.

Rajapaksa R, Fernando CH. 1982b. The Cladocera of Sri Lanka (Ceylon), with remarks on some species. Hydrobiologia 94: 49-69.

Rajapaksa R, Fernando CH. 1985. Reallocation of Indialona macronyx (Daday, 1898) (Cladocera, Chydoridae) to the genus Alona. Can J Zool 63: 970-976.

Rajapaksa R, Fernando CH. 1986a. A review of the systematics and distribution of Chydorus ventricosus Daday, 1889, with the first description of the male and redescription of the species. Can J Zool 64: 818-832.

Rajapaksa R, Fernando CH. 1986b. Tropical species of Kurzia (Crustacea, Cladocera) with a description of Kurzia brevilabris sp. nov. Can J Zool 64: 250-260.

Rajapaksa R, Fernando CH. 1987. Redescription and assignment of Alona globulosa Daday, 1898 to a new genus Notoalona and a description of Notoalona freyi sp. nov. Hydrobiologia 144: 131-153.

Rane PD. 1983. A new species of Cladocera of genus Indialona petkovski (Family Chydoridae) from India. J Bombay Nat Hist Soc 80: 194-195.

Rey J, Vasquez E. 1986. Bosminopsis macaguensis n. sp. et Alona ovata n. sp. (Crustacea, Cladocera), Cladoceres nouveaux du Venezuela. Ann Limnol 22: 219-229.

Sa-ardrit P, Beamish FWH. 2005. Cladocera diversity, abundance and habitat in a Western Thailand Stream. Aquat Ecol 39: 353-365.

Sanoamuang L. 1998. Contributions to the knowledge of the Cladocera of northeast Thailand. Hydrobiologia 362: 45-53.

Sars GO. 1888. Additional notes on Australian Cladocera, raised from dried mud. Forh Vidensk Selsk Kristiania 1888: 1-74.

Sars GO. 1896. On freshwater Entomostraca from the neighbourhood of Sydney, partly raised from dried mud. Arch Math Naturvid 18: $1-81$.

Sars GO. 1903. Freshwater Entomostraca from China and Sumatra. Arch Math Naturvid 25: 1-44.

Scourfield J. 1907. An Alona and a Pleuroxus new to Britain (Alona weltneri Keilhack and Pleuroxus denticulatus Birge). J Queckett Microsc Club 10: 71-76.

Serafim-Júnior M, Lansac-tôha FA, Paggi JC, Velho LFM, Robertson B. 2003. Cladocera fauna composition in a river-lagoon system of the upper Paraná River floodplain with a new record for Brazil. Braz J Biol 63: 349-356.

Shah JA, Pandit AK. 2013. Diversity and abundance of Cladoceran zooplankton in Wular Lake, Kashmir Himalaya. Res J Environ Earth Sci 5: 410-417.
Sharma S. 2008. Notes on some rare and interesting Cladocerans (Crustacea: Branchiopoda) from Meghalaya. Rec Zool Surv Ind 108: 111-122.

Sharma S. 2010. Micro-faunal diversity of Cladocerans (Crustacea, Branchiopoda, Cladocera) in rice field ecosystems of Meghalaya. Rec Zool Surv Ind 110: 35-45.

Sharma P, Kotov AA. 2015. Establishment of Chydorus sphaericus (O.F. Müller, 1785) (Crustacea: Cladocera) in Australia: consequences of mass fish stocking from Northern Europe? J Limnol 74: 225-233.

Sharma BK, Sharma S. 1990. On the taxonomic status of some cladoceran taxa (Crustacea: Cladocera) from Central India. Rev Hydrobiol Trop 23: 105-133.

Sharma BK, Sharma S. 2001. Contribution to the Cladocera fauna (Crustacea: Branchiopda) of Bihar. Rec Zool Surv Ind 99: 31-43.

Sharma BK, Sharma S. 2007. New records of two interesting Chydorid Cladocerans (Branchiopoda: Cladocera: Chydoridae) from floodplain lakes of Assam (N.E. India). Zoos Print J 22: 2799-2801.

Sharma BK, Sharma S. 2008. Faunal diversity of Cladocera (Crustacea: Branchiopoda) of Deepor Beel, Assam (Northeast India): a Ramsar site. J Bombay Nat Hist Soc 105: 196-201.

Sharma BK, Sharma S. 2010. Diversity of Cladocera (Crustacea: Branchiopoda) in floodplain lakes of Manipur, Northeastern India. Rec Zool Surv Ind 110: 19-29.

Sharma BK, Sharma S. 2011. Faunal diversity of Cladocera (Crustacea: Branchiopoda) of Nokrek Biosphere Reserve, Meghalaya, northeastern India. J Threat Taxa 3: 2120-2127.

Sharma BK, Sharma S. 2012. Notes on some rare and interesting Cladocera (Crustacea: Branchiopoda: Anomopoda: Chydoridae) from Deepor Beel, Assam, India. J Threat Taxa 4: 2304-2309.

Sharma BK, Sharma S. 2014. Faunal diversity of Cladocera (Crustacea: Branchiopoda) in wetlands of Majuli (the largest river island), Assam, Northeast India. Opusc Zool Budapest 45: 83-94.

Sharma BK, Hatimuria MK, Sharma S. 2015. Ecosystem diversity of Cladocera (Crustacea: Branchiopoda) of the flood plain lakes of Majuli River Island, the Brahmaputra river basin, north east India. Int J Aquat Biol 3: 78-88.

Sinev AY, 1999. Alona costata Sars. 1862 versus related palaeotropical species: the first example of close relations between species with a different number of main head pores among Chydoridae (Crustacea: Anomopoda). Arthropoda Sel 8: 131-148.

Sinev AY. 2016. Key for identification of Cladocera of the subfamily Aloninae (Anomopoda: Chydoridae) from South-East Asia. Zootaxa 4200: 451-486.

Sinev AY, Korovchinsky NM. 2013. Cladocera (Crustacea: Branchiopoda) of Cat Tien National Park, South Vietnam. J Limnol 72 : 125-141.

Sinev AY, Kotov AA. 2012. New and rare Aloninae (Cladocera: Anomopoda: Chydoridae) from Indo-China. Zootaxa 3334: 1-28.

Sinev AY, Sanoamuang L. 2013. Notes on the cladoceran Pleuroxus (Picripleuroxus) quasidenticulatus (Smirnov, 1996) (Anomopoda: Chydoridae) from South-East Asia and Far East of Russia. Invert Zool 10: 269-280.

Sinev AY, Tiang-nga S, Sanoamuang L. 2017. New genus of Cladocera of subfamily Aloninae (Anomopoda: Chydoridae) from the Mekong River. Zootaxa 4276: 416-426.

Smirnov NN. 1971. The World Chydorid Fauna (in Russian). USSR Academy of Sciences, Zoological Institute Nova Series, Leningrad, 539 p.

Smirnov NN. 1974. Fauna of U.S.S.R. Crustacea, Chydoridae. Vol. 1, No. 2: English Transl., Israel Program Scientific Translation, Jerusalem, $644 \mathrm{p}$. 
Smirnov NN. 1976. Macrothricidae and Moinidae of the world fauna. Fauna SSSR, Novaya seriya. Rakoobraznye 1: 1-237 (in Russian).

Smirnov NN. 1992. The Macrothricidae of the World. Guides to the Identification of the Microinvertebrates of the Continental Waters of the World. The Hague: SPB Academic Publishing, 143 p.

Smirnov NN. 1996. Cladocera: The Chydorinae and Sayciinae (Chydoridae) of the World. In: Dumont HJ, Nogrady T, eds, Guides to Identification of the Microinvertebrates of the Continental Waters of the World: 11. Amsterdam: SPB Academic Publishing, 197 p.

Smirnov NN, Timms BV. 1983. A revision of the Australian Cladocera (Crustacea). Rec Aust Mus Suppl 1: 1-132.

Sousa FDR, Elmoor-Loureiro LMA, Mendonça-Galvão de L. 2013. Cladocerans (Crustacea, Anomopoda and Ctenopoda) from Cerrado of Central Brazil: inventory of phytophilous community in natural wetlands. Biota Neotrop 13: 1-8.

Sousa FDR, Elmoor-Loureiro LMA, Santos S. 2015a. Redescription of Coronatella poppei (Richard, 1897) (Crustacea, Branchiopoda, Chydoridae) and a revision of the genus in Brazil, with descriptions of new taxa. Zootaxa 3955: 211-244.

Sousa FDR, Elmoor-Loureiro LMA, Junior-Debastiani JR, Mugnai R, Senna A. 2015b. New records of Anthalona acuta Van Damme, Sinev \& Dumont 2011 and Anthalona brandorffi (Sinev \& Hollwedel, 2002) in Brazil, with description of a new species of the simplex-branch (Crustacea: Cladocera: Chydoridae). Zootaxa 4044: 224-240.

Subhash Babu KK, Nayar CKG. 2004. Cladocera of Periyar lake and adjacent sites, Thekkady, Kerala. J Bombay Nat Hist Soc 101: 403-414.

Tanaka S, Ohtaka A. 2010. Freshwater Cladocera (Crustacea, Branchiopoda) in Lake Tonle Sap and its adjacent waters in Cambodia. Limnology 11: 171-178.

Taylor DJ, Ishikane CR, Haney RA. 2002. The systematic of Holarctic bosminids and a revision that reconciles molecular and morphological evolution. Limnol Oceanogr 47: 1486-1495.

Van Damme K, Dumont HJ. 2007. Limb morphology of the carnivorous anomopods Anchistropus emarginatus Sars, 1862 and
Pseudochydorus globosus (Baird, 1843) (Crustacea: Branchiopoda: Anomopoda). Ann Limnol - Int J Lim 43: 271-284.

Van Damme K, Dumont HJ. 2008. Further division of Alona Baird, 1843: separation and position of Coronatella Dybowski \& Grochowski and Ovalona gen. n. (Crustacea: Cladocera). Zootaxa 1960: 1-44.

Van Damme K, Dumont HJ. 2010. Cladocera of the Lençóis Maranhenses (NE-Brazil): faunal composition and a reappraisal of Sars, Method. Braz J Biol 70: 755-779.

Van Damme K, Maiphae S. 2013. Salinalona gen. nov., an euryhaline chydorid lineage (Crustacea: Branchiopoda: Cladocera: Anomopoda) from the Oriental region. J Limnol 72: 142-173.

Van Damme K, Sinev AY. 2013. Tropical Amphi-Pacific disjunctions in the Cladocera (Crustacea: Branchiopoda). J Limnol 70: 209-244.

Van Damme K, Kotov AA, Dumont HJ. 2010. A checklist of names in Alona Baird 1843 (Crustacea: Cladocera: Chydoridae) and their current status: an analysis of the taxonomy of a lump genus. Zootaxa 2330: 1-63.

Van Damme K, Sinev AY, Dumont HJ. 2011. Separation of Anthalona gen. n. from Alona Baird, 1843 (Branchiopoda: Cladocera: Anomopoda): morphology and evolution of scraping stenothermic alonines. Zootaxa 2875: 1-64.

Van Damme K, Maiphae S, Sa-ardrit P. 2013. Inland swamps in South East Asia harbour hidden cladoceran diversities: species richness and the description of new paludal Chydoridae (Crustacea: Branchiopoda: Cladocera) from Southern Thailand. J Limnol 72: 174-208.

Ward JV, Tockner K, Schiemer F. 1999. Biodiversity of flood plain river ecosystems: ecotones and connectivity. Regul Rivers 15: 125 139.

Warwick RM, Pearson TH, Rushwahyuni I. 1987. Detection of pollution effects on marine macrobenthos: further evaluation of the species abundance/biomass method. Mar Biol 95: 193-200.

Young SS, Ni MH, Liu MY. 2012. Systematic study of the Simocephalus Sensu Stricto species Group (Cladocera: Daphniidae) from Taiwan by morphometric and molecular analyses. Zool Stud 51: 222-231.

Cite this article as: Gogoi B, Sousa FDR, Das DN. 2018. Faunal diversity of Cladocera (Crustacea: Branchiopoda) with notes on biogeographically important species in the floodplain wetlands of the Subansiri River basin, India. Ann. Limnol. - Int. J. Lim. 54: 36 